\title{
HAMBATAN DAN TANTANGAN ORANG TUA (IBU) PADA SAAT MELAKUKAN PERAWATAN ANAK DENGAN HIV/AIDS (ADHA) YANG MENGAKSES LAYANAN HIV DI KOTA BANDUNG
}

\author{
Gebi E. Nurhayati ${ }^{1}$, Bandu J. Murwasuminar ${ }^{2}$, Laelasari ${ }^{1}$, Abdul Manap ${ }^{1}$ \\ Email: gebi_en@yahoo.com \\ 1. STIKes Dharma Husada Bandung \\ 2. Grha Atma, Pusat Kesehatan Jiwa Masyarakat, Bandung
}

\begin{abstract}
ABSTRAK
Anak dengan HIV/AIDS membutuhkan perawatan orang tua yang lebih komprehensif dibandingkan anak lain pada umumnya karena mengalami masalah pada kesehatan fisik, psikologis, sosial dan spiritual. Orang tua memiliki banyak masalah ketika melakukan perawatan kepada ADHA. Penelitian ini bertujuan mengeksplorasi secara mendalam mengenai hambatan dan tantangan yang dialami orang tua (ibu) dalam merawat anak dengan HIV/AIDS (ADHA) yang mengakses layanan HIV. Metode penelitian menggunakan teknik kualitatif dengan pendekatan fenomenologi. Pemilihan informan penelitian menggunakan purposive sampling pada 6 informan dengan strategi in-depth interview menggunakan voice recorder dan field notes dengan prosedur analisa data 9 tahap Colaizzi. Hasil penelitian mengungkap tiga tema yaitu hambatan dari dalam, hambatan dari luar dan tantangan dalam perawatan. Saran, perlu adanya peningkatan upaya promosi kesehatan kepada masyarakat mengenai cara penularan HIV agar mengurangi stigma dan diskrimnasi pada ODHA.
\end{abstract}

Kata kunci : ODHA, HIV/AIDS

\section{PENDAHULUAN}

Penelitian ini dilatarbelakangi oleh pengalaman peneliti yang pernah bekerjasama dengan Komisi Penanggulangan AIDS (KPA) Kota Bandung dalam campaigns for social change yang bertujuan untuk Say No to HIV/AIDS serta menghentikan stigma \& diskriminasi pada penderita HIV/AIDS. Peneliti melihat bahwa perkembangan penularan HIV/AIDS bukan hanya menyerang populasi kunci saja, tetapi sudah menginfeksi anak yang tertular dari orang tuanya. Pengalaman peneliti juga sesuai dengan ungkapan ketua KPA Kota Bandung:

"Anak yang terinfeksi HIV meningkat setiap tahun karena tertular dari ibu, sebagian besar belum mengetahui status walaupun sudah memasuki usia sekolah dan remaja karena kerahasiaan orang tua. Diperlukan penguatan pada orang tua dan anak agar melakukan pengobatan rutin, siap menerima status kesehatan keluarga, siap akan stigma dan diskrimanasi yang ada di masyarakat serta dibutuhkan pengetahuan dalam perawatan anak di rumah".

Hasil observasi menunjukan bahwa anak yang sudah terinfeksi HIV tetapi tidak mendapatkan pengobatan dan perawatan yang sesuai rentan terserang penyakit. Masalah lain yang terjadi adalah kerahasiaan orang tua pada pengungkapan status anak. Orang tua merasa anak yang mengetahui status akan mengalami masalah kesehatan mental (Hockenberry \& Wilson, 2009). ADHA membutuhkan perawatan klinis, psikis, sosial, ekonomi serta memiliki 
kebutuhan lain untuk memenuhi haknya sebagai anak. Kebutuhan ini berbeda dari waktu ke waktu sesuai dengan perkembangan penyakit dan ketersediaan sistem pendukung dari orang tua dan masyarakat. Penelitian di Brazil, Thailand, Kenya \& Ukraina menunjukan hasil yang positif dilihat dari keberhasilan program terapi Antiretroviral (ARV) pada ADHA (Mahdavi et al., 2010; Willyane \& Giselle, 2014).

Penyakit HIV/AIDS menjadi salah satu masalah kesehatan karena setiap tahunnya terjadi peningkatan jumlah kasus. Publikasi WHO \& UNAIDS (2010) terdapat 33,4 juta orang dengan HIV/AIDS di seluruh dunia dan 2,1 jutanya adalah anak-anak berusia $<15$ tahun. Setiap hari $>1000$ anak di dunia mendapat infeksi baru (WHO, 2011). Dikawasan Asia selatan \& Tenggara, sekitar 270.000 anak sudah terinfeksi (WHO, 2011). Di Indonesia jumlah penderita HIV sebanyak 10.376 orang dan AIDS sebanyak 673 orang (Ditjen P2PL Kemenkes RI, 2017). Presentasi anak dengan HIV/AIDS usia 14 tahun yaitu 1,4\%, dan usia 5-14 tahun yaitu 3,7\% dari jumlah 21.031 kasus (Ditjen P2PL Kemenkes RI, 2011). Kota Bandung merupakan Kota dengan jumlah ODHA terbanyak di Jawa Barat (Sugiharti, Yuniar \& Lestary, 2012). Laporan KPA Kota Bandung tahun 2017 penderita HIV/AIDS umur 0-14 tahun berjumlah 126 kasus (Dinkes Kota Bandung, 2017). Peningakatan jumlah penularan ini apabila tidak dilakukan upaya pencegahan, perawatan dan pengobatan yang komprehensif, dikhawatirkan akan terjadi loss generation seperti yang pernah terjadi di beberapa wilayah sub sahara afrika (KPAN, 2010).

Menurut UNAIDS (2010) Anak sangat rentan tertular HIV, sembilan dari sepuluh anak dengan HIV terinfeksi dari ibunya yang positif pada saat kehamilan, persalinan dan menyusui. Tahun 2008 dinegara berkembang terdapat 430.000 bayi terinfeksi HIV yang tertular dari ibunya (Kemenkes RI, 2011). HIV tidak hanya menyerang kekebalan tubuh, tetapi dapat mengakibatkan tekanan psikologis seperti stress, kecemasan, kemarahan, bahkan mengakibatkan depresi (Ardana, 2014). Individu yang terinfeksi HIV memiliki reaksi psikologis negatif seperti kesulitan menjalin hubungan dengan orang lain (Burhan dkk, 2014).

Penyakit HIV/AIDS menimbulkan kekhawatiran pada orang tua untuk mengungkapkan status kepada anaknya. Alasan utama orang tua tidak mengungkapkan status adalah takut menyebabkan kerugian psikologis pada anak. Hal ini menunjukkan ketidaksiapan pengasuh dan kurangnya pemahaman tentang pengungkapan membuat pengasuh memilih berbohong ke anak. Besarnya stigma sosial menyebabkan orang dengan HIV/AIDS (ODHA) semakin menutup diri tentang keberadaannya dan bisa mempersulit proses pencegahan dan pengendalian infeksi. Stigma dan diskriminasi menyebabkan berkurangnya akses terhadap pelayanan 
sosial, perawatan kesehatan, dan pendidikan (Muhaimin, 2010). Dampak jangka panjang yang ditimbulkan penyakit HIV/AIDS muncul pada aspek pendidikan dan tumbuh kembang anak yang dapat mempengaruhi struktur keluarga (Tao et al., 2010).

Tekanan terbesar yang dihadapi orang tua adalah ketakutan pada perawatan yang dilakukan akan menjadi sia-sia, karena terapi ARV hanya berfungsi menekan perkembangan virus (Hockenberry \& Wilson, 2009). Orang tua terkadang putus harapan dalam membesarkan ADHA sehingga meningkatkan angka kematian anak akibat tidak mendapatkan pengobatan. Menurut UNICEF (2011) hanya sebagian kecil anak yang lahir dengan HIV positif bisa bertahan hidup sampai usia 6 tahun. Tahun 2010 sekitar 1,8 juta orang meninggal karena AIDS, 1 dari 7 orang yang meninggal adalah anak-anak dan setiap jam sekitar 30 anak meninggal karena AIDS (WHO, 2011). Di Indonesia ADHA rata-rata meninggal sebelum usia 5 tahun (Mboi, 2011). Tingginya resiko kematian ini karena infeksi HIV tidak diobati dan tidak mendapatkan perawatan optimal atau adanya penolakan dari orang yang seharusnya menjaga dan merawatnya seperti orang tua, wali dan kerabat (Avert, 2011).

Berdasarkan fenomena diatas, dipandang perlu mengeksplorasi secara kualitatif bagaimana hambatan dan tantangan orang tua dalam merawat anak dengan HIV/AIDS yang mengakses layanan HIV, karena sampai saat ini penelitian sejenis masih sangat kurang, begitu juga di Kota Bandung. Penelitian ini dapat mengidentifikasi permasalahan yang dialami oleh orang tua dalam merawat anaknya, sehingga dapat dijadikan dasar dalam pemberian pelayanan keperawatan atau kesehatan bagi keluarga.

\section{METODE PENELITIAN}

Peneliti menggunakan metode penelitian kualitatif dengan pendekatan fenomenologi. Pendekatan ini berfokus mengeksplorasi dan memahami pengalaman hidup manusia (Satori \& Komariah, 2014; Polit \& Beck, 2010). Analisis menggunakan menggunakan 9 tahap Colaizzi. Untuk mendapatkan kepercayaan penelitian memperhatikan 4 aspek yaitu Creadibility (keterpercayaan data), Transferability (keteralihan data), Dependability (ketergantungan) dan Confirmability. Dalam melaksanakan penelitian peneliti memperhatikan aspek kode etik penelitian.

\section{Sampel Penelitian}

Penelitian dilakukan pada orang tua (ibu) yang merawat ADHA dengan mengakses layanan HIV. Wawancara dilakukan di tempat yang berbeda (cafe, kontrakan, rumah) dan dalam suasana yang nyaman. Populasi penelitian sebanyak 126 orang orang tua yang merawat ADHA berumur 0-14 tahun. Jumlah informan yang terlibat dalam penelitian ini yaitu $6 \mathrm{ibu}$ orang tua ADHA yang mengakses layanan HIV ke Rumah Sakit Hasan Sadikin (RSHS), Rumah 
Sakit Umum Daerah (RSUD) Kota Bandung, Rumah Sakit Bungsu Kota Bandung dan Rumah Sakit Santosa Kota Bandung. Pengumpulan dan validasi data dilakukan selama April-Mei 2018. Kriteria informan adalah: Orang tua (ibu) berstatus positif HIV dan telah menularkan kepada anaknya secara vertikal, merawat ADHA yang berusia 18 bulan-14 tahun dengan mengakses layanan HIV di Kota. Pengambilan informan secara purposive sampling.

\section{Prosedur}

Setelah peneliti mengurus perizinan ke Badan Kesatuan Bangsa dan Politik (Kesbangpol) Kota Bandung dan rumah sakit yang menjadi lokasi penelitian, peneliti melakukan sosialisasi dan pendekatan kepada calon informan untuk mendapatkan persetujuan. Setelah calon informan bersedia, peneliti kemudian membina hubungan saling percaya dan informed consent mengenai tujuan, manfaat dan prosedur penelitian, serta hak dan peran informan selama proses wawancara Selanjutnya informan menandatangani lembar persetujuan dan menentukan waktu serta tempat pengambilan data. Peneliti lalu melakukan wawancara kepada para informan. Peneliti menggunakan alat bantu berupa voice recorder dan field note. Proses pengumpulan data juga kamera video untuk merekam aktivitas informan selama proses wawancara. Hasil wawancara ditranskripkan secara verbatim dan dianalisis. Wawancara dan validasi data dilakukan 2 kali dengan lama waktu bervariasi antara 40-60 menit. Etik penelitian dilakukan.

\section{HASIL PENELITIAN}

Penelitian ini membahas tentang hambatan dan tantangan orang tua merawat anak dengan HIV/AIDS (ADHA) yang mengakses layanan HIV di Kota Bandung. Berdasarkan hasil analisa data, peneliti dapat mengidentifikasi 3 tema pokok dan sub temanya, yaitu:

\section{Tema Pertama (1): Hambatan dan Tantangan Intern (Dalam) \\ Sub Tema Pertama (1.1): Masalah Ekonomi}

ADHA membutuhkan biaya untuk perawatan klinis serta kebutuhan lain untuk menikmati hak-hak mereka sebagai anak. Kebutuhan kasih sayang dan perhatian yang diberikan orang tua kepada anak akan berkurang kapasitasnya akibat dari kesulitan ekonomi (Ernawati, 2013). Hal ini seperti yang diungkapkan oleh ketiga informan berikut:

"Papahnya dua kali masuk rumah sakit... aku harus bekerja karena punya tuntutan kewajiban kerja, kalau masalah si ade dia biayanya dari kakak suami, malah sekolah dari kakak suami, karena mereka merasa bertanggung jawab karena melihat suami aku gak kerja”. (If.3)

"Bapaknya belum sehat bener sekarang di obat juga gak sembuhsembuh soalnya syarafnya sih yang kena... tapi alhamdulillah ibu bisa kerja, bisa menghidupi anak-anak $i b u$ ". (If.4) 
"Saya wirausaha yang memang tidak memiliki gajih tetap untuk hidup sebulan kedepan... control dan ngambil obat, ada pengeluaranpengeluaran yang tidak terduga... siap akan tabungan". (If.6)

Peneliti melihat ibu akan kehilangan pendapatan rumah tangga akibat dari suaminya yang dirawat karena sudah AIDS sehingga kesulitan dalam memenuhi kebutuhan ekonomi serta biaya kesehatan dan tanggung jawab mengasuh ADHA. Menurut UNAIDS (2010) sekitar 16,6 juta anak di bawah usia 18 tahun telah kehilangan salah satu atau kedua orang tuanya karena AIDS yang berisiko terjadi kemiskinan. ODHA akan mengalami kesulitan karena ketidak terjangkauan untuk akses layanan kesehatan sehingga membutuhkan bantuan dari orang paling dekat yang bisa diharapkan memberikan pertolongan. Hal ini didukung oleh pernyataan Rahakbauw (2016) orang tua membutuhkan biaya pengobatan dan transfortasi untuk mengambil ARV atau mengantar anak ke klinik. Hal ini seperti yang diungkapkan oleh informan emapat berikut

"Ibu kan dulu punya BPJS tapi gak punya uang bapaknya gak kerja, jadi hangus udah setahun gak dibayar, sekarang kalau mau berobat yah daftar umum gitu ke teratai 25 ribu berdua jadi 50... belum ongkosnya kesana, kalau obatnya memang gratis, kalau mau periksa CD4 juga bingung, yah ibu suka cari yang gratis aja, ibu ikut gitu, kalau gak ada mah yah gak periksa". (If.4)
Peneliti melihat pekerjaan suami yang tidak menetap akan mengakibatkan gagal menjadi peserta BPJS karena kesulitan membayar premi setiap bulannya. Kesulitan mengakses layanan yang dinyatakan informan disebabkan oleh biaya transportasi, administrasi dan pemeriksaan darah yang terlalu mahal. Hal ini menunjukkan bahwa meskipun obat ARV telah disediakan gratis oleh pemerintah tetapi beban finansial untuk perawatan tetap besar. Menurut Badahdah \& Pedersen (2011) pemberian bantuan misalnya untuk biaya transportasi akan meringankan tanggungan ODHA. Penelitian di Cina, ditemukan bahwa meningkatnya biaya kesehatan untuk penderita HIV/AIDS dapat menghambat akses layanan dan pemenuhan kebutuhan paling dasar (China Nanfang Zhoumo News AIDS Mother, 2004 dalam Ernawati, 2013).

\section{Sub Tema Kedua (1.2): Perasaan sedih dan khawatir dalam melakukan perawatan}

Periode awal kehidupan anak dengan HIV/AIDS merupakan masa-masa tersulit dan paling membebani bagi orang tua. Orang tua pada periode ini sering kali berhadapan dengan permasalahan ketika anak selalu bertanya mengapa mereka harus minum obat setiap hari padahal merasa sehat sehingga membuat orang tua bersedih karena anak mengalami kelelahan dalam berobat. Hal itu diungkapkan oleh kedua informan berikut ini. 
"Yah perasaan ibu gimana gak sedih lah yah, maksudnya lihat si ade masih kecil, bapaknya sakit juga di rumah sakit... aku harus mengurus anak yang masih bayi... satu yang aku susah teh saat dia minum obat, sedihhh banget, awal-awal yang disebut susah yah susah, awalnya nangis" (If.3)

"Ibu mah kepikiran kalau sudah besar mungkin dia bertanya apa gitu saya teh dikasih obat terus, gak seperti orang lain, gak minum juga gak apa apa, ada lah gitu rasa khawatir gitu, kekesal ibu gitu,". (If.4)

Hal tersebut sesuai dengan penelitian Kaay (2016), memberikan hasil bahwa stres karena tekanan hidup yang dirasakan dapat memunculkan reaksi seperti kesedihan serta kesulitan dalam menemukan jalan keluar dari permasalahan yang dihadapi. Menurut Ernawati (2013) beban pengasuhan anak yang teinfeksi HIV/AIDS dapat menimbulkan gangguan emosi karena tuntutan pemberian perawatan. Kecemasan yang dialami kedua informan dikarenakan adanya perasaan berat, kesal serta khawatir. Hal tersebut seperti dalam ungkapan berikut

"Kesel ada, anak susah minum obat ibu bilang ari sia erek kojor gak minum obat... dia gak mau sarapan padahal harus minum obatnya setelah makan, dia suka bilang males minum pagi karena suka ngantuk disekolah, kan emang efek samping obat ngantuk gitu". (If.1)

"Ibu merasa berat ngasih obat ke anak, pertama minum obat pusing, mual, gak bisa tidur, ada efeknya gitu, kelihatan ditunjukan sama dia gitu... awalnya memang khawatir... Yah perasaan sih berat, tapi yah ibu jalani aja, harus gimana lagi kalau gak minum obat yah ngedrop nanti dia nya". (If.4)
ADHA yang mengalami efek samping dari obat ARV akan merasakan hal yang memberatkan sehingga menjadi salah satu faktor ketidakpatuhan. Menurut Yayasan Spiritia (2013) dan Haryatiningsih, Alam \& Sitorus (2017) kepatuhan pada jadwal pengobatan merupakan masalah yang sulit untuk anak. Menurut Sugiharti, Yuyun \& Heny (2014) salah satu faktor penyebab rendahnya kepatuhan minum obat ARV pada ODHA adalah kejenuhan karena harus minum obat yang sama setiap hari dan tidak boleh ada yang terlewat.

Ketergantungan pada perawatan dan pengobatan menimbulkan kecemasan pada orang tua terkait masa depan anaknya. Kaay (2016) bahwa pikiran buruk akan muncul pada ODHA sebagai reaksi kognitif dalam kehidupan mereka ketika lingkungan sekitar mengetahui keadaan individu yang mengidap HIV/AIDS. Hal ini didukung oleh pernyataan Vicki, Anne \& Francesca (2012) bahwa selain menurunkan daya tahan tubuh dan mengakibatkan infeksi oportunistik pada penderitanya, infeksi HIV/AIDS juga menimbulkan masalah psikologi seperti harga diri rendah, kecemasan dan ketakutan. Hal itu diungkapkan oleh informan keenam berikut ini.

"Kalau ada yang nanya saya tidak sanggup bilang dia positif, saya selalu bilang anak saya sehat, anak saya baik, tapi saya tidak sanggup bilang kalau dia terinfeksi HIV”. (If.6) 


\section{Sub Tema Ketiga (1.3): Perasaan bersalah telah menularkan HIV}

Status anak yang terinfeksi HIV tidak dapat terlepas dari status HIV orang tua kandungnya. Orang tua pada umumnya mengalami kecemasan dan merasa bersalah karena bertanggung jawab pada apa yang menimpa anaknya. Hal tersebut seperti dalam ungkapan berikut ini.

"Terus terkena virus dari aku
juga...gimana aku gak terpuruknya
gitu, kenapa harus sama anak gitu, ya
udah aku aja gitu jangan sampai
terkena dari aku... kalau misalkan gak
ada penyakit dari aku, karena aku
yang menularkan... itu sakit dari aku
gitu istilahnya mah yah, jadi aku
ngerasa aku yang bersalah banget,
makanya aku kalau ada apa apa sama
si dede sampai nangis nangis, gak
bisa gitu, itukesalahan aku(If.3)

"Ibu dulunya gak tahu kalau harus di caesar, yah kasian kenapa kena ke anak, padahal kan kenapa gak ke ibu aja gitu”. (If.5)

Peneliti melihat perasaan bersalah muncul karena adanya suatu penyakit dari orang tua yang ditularkan pada anaknya sehingga mengakibatkan kemarahan, kesedihan, kecemasan dan penyangkalan. Hal ini sejalan dengan lima tahapan berduka menurut Kubler-Ross dalam Nugraha (2011) yaitu tahap denial (penyangkalan), angry (kemarahan), bargaining (tawar-menawar), depression (depresi) dan acceptance (penerimaan).

\section{Sub Tema Keempat (1.4): Takut untuk membuka status kepada anak sehingga memilih berbohong demi masa depannya}

Orang tua yang merawat ADHA biasanya akan mengalami masalah pada pengungkapan dan memilih merahasiakan status kepada anaknya. Orang tua masih merahasiakan status HIV dari anak mereka karena merasa anak yang mengerti status akan mengalami depresi atau masalah kesehatan mental sehingga melindungi anak dari kekhawatiran masa depannya. Hal tersebut diungkapkan oleh kedua informan berikut.

\begin{abstract}
"Anak ibu belum tahu dia statusnya HIV, dari dokter sama petugas kesehatan di poli anak juga menyarankan jangan dulu ngasih tahu, ibu siapnya kasih tahu pas kelas 3 SMP aja. Pokoknya mah belum waktunya biarkan aja dulu... Takutnya down, terus frustasi”. (If.1)

"Anak saya kan sekarang 11 tahun, memang dia sudah mengerti tapi belum memahami... sekarang posisinya saya belum open ke anak, anak belum tahu statusnya punya penyakit seperti ini gitu... dia tidak menerima, dia berontak, itu yang saya takutkan, semua orang tua tanya apa yang ditakutkan pasti berontak”. (If.2)
\end{abstract}

Pernyataan informan bertolak belakang dengan Yayasan Spiritia (2014) yang menyatakan bahwa anak yang diberitahu telah terinfeksi HIV sebelum usia enam tahun memang tidak mempunyai arti baginya, tetapi pada usia 7-10 tahun infeksi HIV dapat diartikan harus minum obat agar badan tetap sehat dan bisa melawan kuman, sementara pada usia 10-13 tahun setiap anak 
sebaiknya tahu status HIV mereka dalam pengungkapan penuh karena pada usia ini anak dapat mengerti bahwa dia hidup dengan penyakit menahun yang disebut HIV dan menyadari apa yang perlu dilakukan agar badan tetap sehat.

Orang tua juga menunggu waktu yang paling cocok untuk pengungkapan serta tergantung pada kesiapan orang tua dan anak itu sendiri. Hal serupa juga diungkapkan oleh kedua informan berikut ini

"Kalau sekarang aku ngomong langsung ke dia yang aku takutkan yah jadi broken, nanti dia nya minder, gak mau ini, gak mau itu, aku nya banyak ketakutan... terus dia kabur nauduzubilahimindzalik dia sampai bunuh diri, nah aku gak mau kejadian seperti itu... aku takutnya suatu saat dia tahu status dia, dan dia minder terus berontak”. (If.3)

"Beban ibu sebenarnya takut, entar ngomong ke dia punya penyakit ini, karena nanti kalau mau ngomong dia tidak menerima... tapi nanti aja kalau dia sudah gede ngomongnya, pas dia sudah SMP, tapi ibu juga bingung belum ada persiapan, gak akan ngomong dulu status ini sekarangsekarang, ibu juga suka ngobrol ke WPA, gimana caranya membuka status kalau dia sudah gede, emang agak takut juga”. (If.5)

Orang tua biasanya mencari informasi dari para medis dan orang-orang yang sudah berpengalaman dalam menghadapi pengungkapan status ADHA. Proses pengungkapan HIV membutuhkan kerja sama dan keterlibatan dari pihak yang sesuai untuk memberi dukungan pada ADHA. Menurut Yayasan Spiritia (2014) anggota jaringan dukungan ADHA meliputi orang tua, pengasuh, keluarga, guru, petugas kesehatan serta anggota LSM. Peneliti melihat bahwa, proses pengungkapan status HIV pada anak dilakukan secara berlanjut dan hati-hati serta dibutuhkan kesiapan dari anak itu sendiri, pengasuh, juga penyedia layanan kesehatan. Sementara penelitian yang dilakukan di Thailand mengenai sikap pengasuh ADHA terhadap pengungkapan status ditemukan, dari 49 pengasuh yang belum mengungkapkan kepada anak mereka, $37 \%$ dari mereka tidak berniat untuk itu dengan alasan utamanya adalah takut menyebabkan kerugian psikologis pada anak dan hanya $17 \%$ yang bermaksud untuk mengungkapkan jika ditanya oleh anak (Arida, 2007 dalam Ernawati, 2013).

Orang tua ada juga yang sudah memberitahu anaknya sejak kecil bahwa dia terinfeksi HIV walaupun anak tidak mengerti maknanya. Anak dapat mempertahankan kepatuhan pengobatan dengan memaknai ARV sebagai vitamin sehingga membuatnya merasa lebih sehat seperti fungsi vitamin yaitu meningkatkan daya tahan tubuh. Hal ini diungkapkan oleh informan berikut.

"Dia kan masih belum tahu, belum mengerti... kalau dia minum ARV aku bilang ini vitamin... sekarang mah vitamin aja dulu”. (If.3)

"Pokoknya kasih tahunya itu vitamin aja, kadang temen-temen sekolahnya juga suka nanya kalau suka main, kenapa minum obat, obat apa itu, vitamin biar sehat gitu”. (If.4) 
"Kadang dia nanya kenapa minum obatnya tiap hari, kan ini vitamin gitu ibu bilangnya, emang harus diminum tiap hari, mamah juga minum gitu. ibu belum bisa menjelaskan tuh karena dia belum paham gitu dengan penyakit HIV”. (If.5)

Pemahaman ARV sebagai vitamin agar tetap sehat dapat mengurangi beban anak dalam menjalani pengobatan. Hal ini sesuai dengan penelitian Walter (2010) di Peru bahwa ODHA memiliki strategi dalam pengobatan dengan menganggap obat sebagai vitamin sehingga cenderung meningkatkan kepatuhan.

\section{Sub Tema Kelima (1.5): Kurangnya pengetahuan orang tua}

Pengetahuan yang diperoleh dari kehidupan sehari-hari baik itu pendidikan maupun pekerjaan dapat membentuk perilaku seseorang. Menurut Shintawati (2014) faktor yang mempengaruhi perilaku orang tua dalam memberikan perawatan kepada anaknya adalah pengetahuan yang cukup. Hal tersebut seperti yang diungkapkan oleh ketiga informan berikut.

"Ibu sering ikut jadi testimoni acara untuk cerita bagaimana menjadi ODHA gitu... ibu juga tahu da ikut pelatihan atuh". (If.1)

"Aku tuh udah mempelajari semuanya gitu alhmdulillah... aku masih ikut pelatihan dari LSM gitu”. (If.3)

"Ibu juga suka dibantu WPA, kadang di ajak rapat kemana... Ibu sering ikut konseling ke dokter ke WPA, terus didampingi”. (If.5)
Adanya kelompok swadaya dalam masyarakat yang memberikan informasi, pendidikan, konseling, menyediakan pelayanan klinis dan membentuk keterampilan berbasis perawatan dirumah akan mendukung perawatan jangka panjang pada ADHA (Legiati, Shaluhiyah \& Suryoputro, 2012). Orang tua dalam memberikan perawatan kepada anak harus memiliki kemampuan mengenal masalah yang meliputi pengertian, tanda \& gejala, penyebab, kemampuan mengambil keputusan mengenai tindakan perawatan yang tepat dan menggunakan pelayanan kesehatan di masyarakat (Tindyetwa et al, 2011). Hal tersebut seperti yang diungkapkan oleh informan kedua berikut ini.

\footnotetext{
"Saya tahu kondisi anak HIV itu labil gitu, gak seperti anak yang lain, walaupun CD4 nya baik, mudah terserang penyakit apabila kurang menjaganya, daya tahan tubuhnya gampang merosot, walaupun konsumsi vitamin penuh, ada kalanya dia ngedrop... saya selalu konseling yah sama dokter... walaupun dikampung tapi saya yang tahu kondisinya anak seperti apa”. (If.2)
}

\section{Sub tema keenam (1.6): Mengetahui status anak positif HIV tidak sejak dini}

Anak yang tertular HIV dan sudah memasuki tahap AIDS sering mengalami infeksi baik karena virus maupun bakteri. Hal itu dinyatakan oleh ketiga informan berikut ini.

"Pas 2012 karena baru ketahuan positif HIV pernah drop... terus diperiksa darah pas sakit 2 minggu di rawat RSHS" (If. 1) 
"Dari dia usia 3 tahunan... memang kondisinya ngedrop, kecil gitu... tahun 2010 sejak ayahnya meninggal, ayahnya di VCT, diketahui punya penyakit $H I V ”$. (If. 2)

"Awalnya ibu tertular dari suami yang dulu... anak diketahui tahun 2010, diperiksa di Hasan sadikin”. (If.5)

Keberadaan virus HIV dalam tubuh anak dapat diketahui melalui pemeriksaan laboratorium pada sampel cairan tubuh seperti darah (Puluningsih, 2010). Biasanya pemeriksaan VCT pada anak dilakukan setelah salah satu orang tuanya meninggal karena AIDS. Hasil penelitian Khairurrahmi (2009) menunjukan bahwa penularan HIV dari ibu ke bayi kemungkinan berasal dari seorang laki-laki HIV positif yang menularkan kepada pasangan perempuannya melalui hubungan seksual tidak aman dan selanjutnya pasangan perempuan itu menularkan kepada bayi yang dikandungnya. Hal tersebut diungkapkan oleh kedua informan berikut ini.

"Awalnya ketahuan si ade umur 2 tahun, karena waktu itu pertama ngedrop itu suami, terus suami ketahuan positif, terus dokter menyarankan untuk cek semua anggota keluarga”. (If. 3)

"Awalnya memang saya terinfeksi dari almarhum suami saya... anak ibu positif karena ibu menyusui sih, padahal lahirannya caesar”. (If.6)

Anak yang statusnya masih berada pada fase HIV memang tidak menampakkan gejala, kecuali sudah masuk ke dalam fase AIDS (KPAN, 2011).

\section{Tema Kedua (2): Hambatan Ekstern (Luar) \\ Sub Tema Pertama (2.1): Stigma}

Stigma yang dilakukan masyarakat awam biasanya karena ada pandangan buruk bahwa ODHA sangat memalukan telah memiliki penyakit HIV/AIDS. Hal ini seperti yang diungkapkan oleh kedua informan berikut.

"Kadang ada yang bikin sakit hati mah ngomong tentang anak gitu, tapi yah ibu mah diem aja, kita sudah terbiasa, jadi cuek aja biarkan, kalau di posyandu ada lah ibu-ibu kader, pake sarung tangan gitu”. (If.1)

"Kalau saya dapat stigma dan tersinggung saya marah-marah gitu, pada petugas kesehatan juga, saya gak mau dia kecewa, disakitin... saya gak ingin anak saya sedih... saya takut stigma dan diskriminasi akan bikin dia seperti gara-gara ini dia dijauhi”. (If.6)

Peneliti melihat ibu yang memiliki anak dengan penyakit HIV/AIDS tidak jarang mendapatkan stigma dari masyarakat. Padahal menurut Undang-Undang Dasar 1945 tentang Perlindungan Anak tercantum dalam Pasal 28 Ayat (2) bahwa perlindungan anak adalah "Segala kegiatan untuk menjamin dan melindungi anak dan hakhaknya agar dapat hidup, tumbuh, berkembang, dan berpartisipasi, secara optimal sesuai dengan harkat dan martabat kemanusiaan, serta mendapat perlindungan dari kekerasan". 


\section{Sub Tema Kedua (2.2): Diskriminasi}

Selain itu, doskriminasi dapat terjadi kepada ADHA. Diskriminasi bukan hanya didapatkan dari masyarakat tetapi dilakukan juga oleh petugas di layanan kesehatan tempat ODHA mencari perawatan. Hal tersebut seperti yang diungkapkan oleh kedua informan berikut ini.

“Dipukesmas juga pake sarung
tangan sampai 5 lapis... kalau di IGD
juga, berobat juga dihiraukan, pas
anak drop yah, para perawatnya tahu
statusnya, padahal mereka kan ngerti
yah gimana penularannya, sarung
tangan tebel pas mau pasang infus...
Pernah ada yang ngomong jangan
pake bantal, padahal kan gak menular
lewat keringat yah, padahal mereka
kan lebih tahu, apakah nunggu kita
kojor dulu gitu yah”. (If.1)

"Awal awal... karena aku bilang aku B20 aku sampai dijauhin, penanganan nya itu langsung menjauh". (If.3)

Peneliti melihat diskriminasi dapat terjadi dalam pelayanan kesehatan yang menunjukan kearah penghinaan atau perlakuan kasar. Hasil penelitian Chambers et al. (2015) di Canada ditemukan masih ada stigma dan diskriminasi pada ODHA dari petugas kesehatan, meskipun mereka dibekali tentang pengetahuan HIV/AIDS. Hal tersebut didukung oleh pernyataan Wachdin, Murti \& Demartoto (2017) bahwa stigma oleh petugas kesehatan juga ditunjukkan melalui justifikasi bahwa ODHA adalah orang yang berbeda dan dianggap tidak normal. Menurut Wahyuni \& Rahayu (2013) stigma dari masyarakat yang dialami ODHA adalah perlakuan berbeda dibandingkan dengan orang yang menderita penyakit lain sehingga banyak ODHA tidak membuka identitas dirinya. Hal ini diungkapkan oleh kedua informan berikut ini.

\begin{abstract}
"Saya gak open ke sekolah tetang kondisinya, maksudnya gak ada yang tahu lah, udah aja cukup kita aja takutnya ada hal hal lain... justru kalau open yang saya takutkan dapat menstigma dan diskriminasi anak saya... namanya juga dikampung, karena orang beda yah, tingkat pendidikannya mungkin bisa mempengaruhi juga, kalau namanya diluar yah pikirannya beda". (If.2)

"Dia harus belajar ini merupakan sebuah proses, diluar sana ada stigma dan diskriminasi yang sangat besar, selama ini yah kalau sudah waktunya minum obat padahal banyak orang, dia harus sembunyi, bisa-bisanya kita jaga, dia memang terjaga status kesehatannya". (If.6)
\end{abstract}

Peneliti melihat bahwa orang tua masih menutup status penyakit anaknya ke sekolah karena takut akan stigma dan diskriminasi yang bisa saja dilakukan guru atau temannya sehingga mengakibatkan ADHA ditolak dilingkungan sekolah. Hal ini sesuai dengan hasil penelitian di Negara Kamboja yang melaporkan bahwa 76 dari 100 ODHA mendapatkan stigma dan diskriminasi (Lubis, Sarumpaet \& Ismayadi, 2016). Hal tersebut juga didukung oleh hasil penelitian di Negara Zimbabwe oleh Campbell et al. (2010) yang menunjukan bahwa teman di sekolah juga dapat memberikan stigma terhadap ADHA yang disebabkan oleh penyakit yang diderita atau keadaan fisiknya. 


\section{Tema Ketiga 3: Tantangan Dalam Perawatan \\ Sub Tema Pertama (3.1): Kewajiban minum obat ARV secara teratur}

Anak yang sudah didiagosa HIV/AIDS harus rutin setiap hari minum obat ARV (Antiretroviral) untuk menekan perkembangan virus dalam tubuhnya. Jenis obat yang paling banyak dikonsumsi ODHA adalah obat dengan 3 kombinasi ARV lini pertama. Hal tersebut diungkapkan oleh keempat informan berikut ini.

"Ada 3 macam diminum jam 6 pagi, zidovudin, lamivudin, sama kotri untuk daya tahan tubuh itu antibiotic... kalau yang pagi jam 6 sebelum berangkat sekolah 2 macam, malam jam 6 juga". (If. 1)

"Eee kalau sekarang mah kotrimoxazole masih masuk jam 7 pagi karena ARV masuk jam 7 pagi dan jam 7 malam”. (If.2)

"ARV di ambil di RS Bungsu setiap bulan sekali, kan memang kesana kontrolnya, dia minum 2 kali sehari, pagi dan malam, minumnya dia rutin dari tahun 2010” (If.5)

"Paling terapi ARV, itu aja sih... ada 3 macam, itu ada lamipudine \& zidopudine itu jadi satu kapsul merek dagangnya dupiral satu pagi satu malam, kalau evapirenz malam aja... resep ARV diambil di RS Bungsu” (If.6)

Ibu datang ke layanan HIV sebulan sekali pada waktu yang sudah ditetapkan untuk diberikan persediaan ARV. Kepatuhan pengobatan berhubungan dengan perilaku mengambil obat. Berdasarkan data dari Kemenkes RI (2011). Sebanyak 80\% ODHA masih menggunakan ARV lini pertama yaitu zidovudin, lamivudin, nevirapin, efavirenz dan tenofovir. Sebanyak 16,7\% diganti dengan ARV lain tetapi masih lini pertama dan $4 \%$ sudah diganti oleh lini kedua yaitu ritonavir atau lopinavir. Menurut WHO (2011) pengobatan ARV kombinasi dosis tetap mulai banyak digunakan di negara lain karena mudahnya pemberian obat tersebut. Yayasan Spiritia (2013) menyatakan selain pengobatan ARV kombinasi, anak juga akan mendapatkan obat kotri yang mengandung antibiotik sulfametoksazol dan trimethoprim untuk mengurangi beban infeksi menular, mengobati diare dan infeksi oportunistik.

Kualitas hidup anak yang menderita HIV/AIDS sebagian besar tergantung pada kepatuhan terapi ARV. Studi penelitian di Thailand, Kenya \& Ukraina menunjukan hasil yang positif dilihat dari keberhasilan program terapi ARV pada anak (Mahdavi et al., 2010). Hal tersebut diungkapkan oleh informan berikut ini.

"Jadi lebih rutinnya ke pengobatan ARV itu, jangan bolong-bolong... nanti sakit gak sekolah lagi... ya gitu lah ngerawatnya mah... saya selalu tepat waktu dalam memberikan obat... yang utamanya jangan sampai telat $A R V$ nya"(If.2)

"Yang penting kan nomor satu obat... Aku penanganannya cuma minum obat ARV... sekarang dia suka ngingetin" (If. 3)

Menurut Yayasan Spiritia (2013) bagi ODHA terapi ARV bukan hanya pengobatan biasa tetapi bermakna harapan untuk memperbaiki kualitas dan keberlangsungan 
hidup. Selanjutnya, Teori Health Belief Model mengatakan bahwa tindakan seseorang untuk rutin pengobatan ARV didorong oleh ancaman penyakit HIV/AIDS (Legiati, Shaluhiyah \& Suryoputro, 2012). Walaupun orang tua selalu mengingatkan dan membiasakan anak minum obat pada waktu yang sama setiap hari tetapi bisa saja anak kelupaan dan kadang mengeluh sudah bosan. Seperti ungkapkan kedua informan berikut ini.

"Kalau terlambat keluhan dia suka kesemutan kaki... 2 hari setelahnya itu pusing, panas dingin.... kalau ibu mengingatkan pasti diminum, kalau gak mah main kemana sampai lupa minum". (If.1)

"Keluhan anak ada aja sih minum obat-obatan terus terusan tiap hari sudah sekian tahun, ada lah rasa bosen pasti, itu normal, manusiawi”. (If.2)

Peneliti melihat bahwa ODHA harus minum obat ARV seumur hidupnya sehingga dapat menjadi beban pada moril, fisik dan mental. Beban tersebut makin memberatkan ODHA apabila mengalami dampak dari keterlambatan minum obat seperti pusing, demam dan mengalami gangguan perifer seperti kesemutan dan pegal. Menurut Felix \& Ceolim (2012) alasan ODHA sering melewatkan dosis ARV secara tidak sengaja dikarenakan lupa.

\section{Sub Tema Kedua (3.2): Harus Rutin pemeriksaan CD4 \\ CD4 (Cluster of differentiation 4)} merupakan komponen dari sel darah putih manusia yang dirusak oleh HIV ketika terjadinya penularan sehingga ODHA memiliki sistem kekebalan tubuh yang lemah dan mudah terkena infeksi. Kerusakan imunologi pada ODHA dapat ditandai dengan melihat jumlah CD4 sebagai indikatornya. Pemeriksaan jumlah CD4 sangat penting untuk mengetahui progresivitas infeksi HIV. Hal tersebut seperti diungkapkan oleh keempat informan berikut.

"Ya kalau perawatan utama yang saya lakukan... cek CD4 ke rumah sakit RSHS, itu aja yang rutin saya lakukan... per 6 bulan sekali kita CD4. Pas usia 3 tahun pas di cek CD4 memang sudah rendah jadi yang duluan masuk ARV anak saya”. (If.2)

"Dia 3 bulan sekali diambil darah". (If.3)

"Kalau mau periksa CD4... harus diperika 3 bulan sekali”. (If.4)

"Terus pemeriksaan CD4 untuk cek darah setahun 2 kali”. (If.5)

Untuk menilai keparahan penyakit HIV/AIDS seseorang yaitu dengan melihat status imunitasnya dari pemeriksaan jumlah CD4. Pemeriksaan ini melengkapi pemeriksaan klinis untuk menentukan pasien yang memerlukan pengobatan infeksi oportunistik dan memulai terapi ARV. Berdasarkan Kebijakan Pedoman ARV (2011), untuk memulai terapi ARV pada pasien HIV/AIDS yaitu dengan jumlah 
CD4>350 sell $/ \mathrm{mm}^{3}$ tanpa memandang stadium klinisnya. Menurut Cohen dkk (2011) jumlah CD4 menjadi salah satu parameter untuk pemberian terapi serta pemantauan infeksi oportunistik. Pemeriksaan jumlah CD4 sebaiknya diulang setiap 3-6 bulan pada pasien yang menggunakan terapi ARV untuk memantau sistem kekebalan tubuhnya. Manfaat ARV untuk pengobatan HIV/AIDS adalah mengurangi jumlah virus dalam darah, meningkatkan jumlah sel CD4 sehingga ODHA merasa lebih baik yang pada akhirnya dapat meningkatkan kualitas hidupnya (KPAN, 2010). Penelitian Dalmida dkk (2009) di Afrika \& Amerika menunjukan bahwa semakin tinggi nilai CD4 pada pasien HIV/AIDS maka sistem imunnya berada dalam keadaan baik. Pasien dengan CD4 di bawah batas normal sangat rentan terhadap berbagai penyakit infeksi oportunistik. Hal tersebut seperti yang diungkapkan ketiga informan berikut ini.

"Dulu CD4 nya pernah 50, rutin minum obat sekarang 285 pas periksa kemarin”. (If.1)

"Masuk rumah sakit CD4 nya sampai 88 baru kemarin cek 171 ke dokter". (If.3)

Orang tua beranggapan bahwa apabila anaknya rutin minum obat $\mathrm{ARV}$, maka dapat meningkatkan jumlah sel CD4 dan sistem imunnya akan membaik. Hal ini sejalan dengan pernyataan Kemenkes RI (2011) bahwa jumlah CD4 menjadi tolak ukur status kesehatan ODHA dan sebagai indikator kegagalan imunologis karena terapi ARV yang buruk. Jumlah CD4 normal adalah $410-1590 \mathrm{sel} / \mathrm{mm}^{3}$ dan bila CD4 $<350 \mathrm{sel} / \mathrm{mm}^{3}$ bisa dikatakan AIDS. Infeksi oportunistik biasanya tidak terjadi pada ODHA hingga jumlah CD4 turun dari kadar normal sekitar 500-2000 sel/ L menjadi kurang dari $200 \mathrm{sel} / \mathrm{mm}^{3}$. Penderita dengan jumlah CD4 >200 sel $/ \mathrm{mm}^{3}$ memiliki kerentanan enam kali lebih besar untuk infeksi oportunistik dibandingkan dengan jumlah CD4 >350 sel $/ \mathrm{mm}^{3}$ (Ghate, et al., 2009). Pedoman Nasional Pengobatan ARV (2011) menjelaskan bahwa rata-rata penurunan CD4 sekitar 70-100 $\mathrm{sel} / \mathrm{mm}^{3} /$ tahun dan terjadi peningkatan setelah pemberian ARV antara 50-100 $\mathrm{sel} / \mathrm{mm}^{3} /$ tahun dengan monitoring setiap 6 bulan. Hal ini seperti yang diungkapkan oleh kedua informan berikut

"Kalau gak tepat waktu minum obat kelihatan, kalau tepat waktu bisa naik CD4 nya... minum obat waktunya gak teratur, malah turun CD4 nya, kalau gak pas gitu jam nya,". (If.4)

"Paling control... setiap bulan harus ke dokter, control untuk pemeriksaan darah, viralllod dan yang lainnya... dia tahu harus cek darah untuk monitor keberhasilan pengobatan dan kesehatannya”. (If.6)

Pemantauan viral load dapat mengukur jumlah replikasi virus HIV dalam darah. Hal ini sejalan dengan pernyataan WHO \& UNAIDS (2009) bahwa pemeriksaan CD4 dan jumlah viral load pada penderita HIV yang mendapatkan ARV dilakukan untuk pemantauan terapi. ARV bekerja dengan 
cara mengurangi jumlah virus yang menginfeksi CD4 sehingga sistem kekebalan tubuh dilindungi dari kerusakan yang ditunjukkan dengan peningkatan jumlah sel CD4. Terapi ARV digunakan secara jangka panjang sehingga memerlukan pemeriksaan CD4 yang rutin untuk melihat keefektifan pengobatan (Nursalam \& Kurniawati, 2013).

\section{Sub Tema Ketiga (3.3): Mencari perawatan bila anak sakit}

Anak yang sudah terinfeksi HIV akan rentan terserang penyakit apabila tidak mendapatkan pengobatan dan perawatan yang sesuai. Menurut WHO (2011) salah satu cara mengatasi perubahan fisik yang ditimbulkan akibat HIV/AIDS yaitu meningkatkan cakupan pengobatan, dukungan dan perawatan. Hal tersebut diungkapkan oleh kedua informan berikut ini.

\footnotetext{
"Yang ibu lakukan selalu dikonsulkan dulu ke dokter sama petugas kesehatan... Pernah 2 bulan kan drop yah, di opname 2 minggu... ibu mah kalau stok obat habis buat si kakak yah ibu ambil ke UGD buat sehari” (If.1)
}

Peneliti melihat bahwa orang tua akan segera mencari perawatan medis apabila anaknya sakit. Menurut Legiati, Shaluhiyah \& Suryoputro (2012) bahwa konsultasi dengan petugas kesehatan akan memberikan pemahaman yang benar tentang kerentanan dan keparahan suatu penyakit. Teori Health Belief Model mengatakan bahwa tindakan seseorang untuk mencari pengobatan atau pencegahan didorong oleh ancaman penyakit tersebut (Legiati, Shaluhiyah \& Suryoputro, 2012). Hal tersebut diungkapkan oleh ketiga informan berikut ini.

"Ngedropnya itu panas, dari panas aja, jadi panasnya gak berhenti berhenti, udah pake apa-apa, panas tingggi terus, aku lariin ke rumah sakit”. (If.3)

"Dia kalau ngedrop itu pasti diem... dia gak enak badan gitu, lemes, demam, pusing, paling tiduran, dikompres, minum obat paracetamol... ke dokter, pokoknya jangan sampai terlambat... kalau gak bisa, saya selalu ke puskesmas, gak disimpen gitu anak teh (If.2)

\section{Menurut Ernawati (2013) tugas} kesehatan keluarga meliputi kemampuan keluarga untuk mengenal masalah kesehatan, memutuskan tindakan, merawat anggota keluarga yang sakit, memodifikasi lingkungan dan memanfaatkan fasilitas pelayanan kesehatan. Friedman, Bowden \& Jones (2010) juaga mengungkapkan bahwa orang tua terlibat dalam pengambilan keputusan untuk memilih proses terapi pada anaknya disetiap tahapan sehat dan sakit. Hal itu diungkapkan oleh informan ketiga berikut ini.

\footnotetext{
"Pernah pengobatan ke pak haji ngobatin si ade, sampai dibawa ke mana-mana, dibawa ke garut, dibawa kesana kesini... ke dokter mah harus, berdoa harus, berikhtiar harus, medis mengatakan gak ada yang dapat menyembuhkan, tapi aku jalani”. (If.3)
}

Peneliti melihat orang tua akan mempertahankan keadaan kesehatan 
anaknya dengan menggunakan pengobatan medis yang bertujuan untuk menghilangkan rasa sakit dan berkunjung ke tempat praktek spiritual atau doa untuk mencari ketenangan.

\section{Sub Tema Keempat (3.4): Memenuhi kebutuhan nutrisi}

Pemenuhan nutrisi pada ADHA umumnya tidak berbeda dengan yang diberikan pada anak lainnya. Menurut UNICEF (2010) keluarga berperan dalam meningkatkan status kesehatan, mengatasi HIV/AIDS, termasuk pemberian obat dan pemenuhan nutrisi anak sehingga mengurangi rawat inap di rumah sakit. Gizi yang adekuat dapat mencegah kurang gizi, menghambat perkembangan virus, mendukung efektivitas perawatan dan pengobatan serta meningkatkan daya tahan tubuh terhadap infeksi oportunistik. Hal tersebut seperti yang diungkapkan oleh informan berikut ini.

"Paling roti, donat, kalau yang utamanya sayuran, kami selalu konsumsi sayuran, tahu, tempe, selalu ada, itu selalu dipaksain". (If.2)

"Kalau makanan biasa aja, ibu seadanya kayak telor ada juga... itu aja sih dari makanan, susu, telur itu juga kalau ada rezekinya”. (If.4)

"Pokoknya makan tepat waktu, makan yang bener, maksudnya makan nasi dan lauk 4 kali sehari, pagi siang sore dan malam... porsi banyak". (If.6)

Asupan gizi yang optimal berfungsi membantu meningkatkan kesehatan dan kualitas hidup ADHA. Menurut Fathimah (2013) kebutuhan energi untuk ADHA lebih besar $10 \%$ dari anak lainnya, karbohidrat sangat dibutuhkan untuk menghasilkan energi, protein sebesar $12-15 \%$ dibutuhkan untuk memelihara sel dan jaringan tubuh termasuk pembentukan antibodi, lemak dalam jumlah $10-25 \%$ dari kebutuhan energi total merupakan cadangan energi tubuh paling besar. Kemenkes RI (2010) juga menambahkan bahwa ADHA disarankan mengkonsumsi protein dari sumber hewani dan nabati seperti telur, ayam, ikan, daging, susu dan produk olahannya yang dapat membantu mempertahankan otot. Hal tersebut diungkapkan oleh ketiga informan berikut ini

"Kan dikasih susu dari KPA buat anak ODHA tapi dia suka gak mau, kalau susu kaleng beli di supermarket, dia mau dan diminum”. (If.1)

"Vitamin, paling susu, kalau susu kadang mau kadang gak, namanya juga anak... susu selalu sedia dirumah". (If.2)

"Suka ada bantuan juga, dari susunya dulu dapat dari dinas sosial, dulu dikasihnya uang, dibelanjakan... alhamdulillah begitu daya tahan tubuhnya jadi bagus ke badannya". (If.4)

Orang tua juga memberikan minuman madu kepada anaknya sebagai obat berbagai macam penyakit. Hal tersebut diungkapkan oleh kedua informan berikut ini.

"Paling madu, buat daya tahan tubuhnya gitu, buat stamina, alhamdulillah... sistem imun tubuhnya bagus gitu... Itu aja beli madu, ibu kasih pagi sama sore, suka kelihatan makannya agak enak, suka kelihatan 
badannya seger kalau dikasih madu”. (If.4)

“Paling vitamin kayak madu” (If.6)

Madu bisa digunakan untuk suplementasi nutrisi bagi individu yang sehat juga sebagai antioksidan dan antibakteri yang mempercepat penyembuhan luka. Menurut Hotnida (2011) manfaat madu untuk kesehatan adalah multikhasiat dalam menyembuhkan penyakit. Selain itu kemenkes RI (2010) menyarankan bahwa makanan yang dipilih disesuaikan dengan batasan pemenuhan gizi pada pasien yang diresepkan. Hal tersebut diungkapkan oleh kelima informan berikut ini.

“Makannya dijaga jangan yang pedes, jangan yang bersoda...cuma makanan pedes banget itu tidak diperbolehkan, kan kalau status ODHA kalau sudah sakit perut kan bisa drop parah, susah buat adaptasinya kata dokter... makan duren pernah drop".(If.1)

"Harus hati-hati dari makanannya, dia gak pernah jajan yang sembarangan, pokoknya mending dia nangis aja dari pada jajan sembarangan, bapaknya juga begitu, neneknya juga begitu memeperlakukannya”. (If.3)

"Ibu gak tahu sih jajannya suka sembarangan gitu... makanannya selalu dijaga yah, harus bergizi, kan yang punya HIV mah sensitif gitu yah rentan terhadap penyakit”.(If.4)

"Karena dia pencernaan sudah sensitive jadi kita punya jadwal dia untuk mie instan, makan mie instan sebulan dua kali”. (If.6)

\section{Sub Tema kelima (3.5): Menanamkan pondasi yang kuat kepada anak}

ADHA tetap perlu untuk mencapai tahapan perkembangan seperti anak yang sehat pada umumnya. Menurut Marlinda (2011), tugas-tugas perkembangan anak usia sekolah adalah mengembangakan kemampuan dasar dalam belajar, bergaul, menggunakan kemampuan fisik dan mengembangkan konsep hidup serta moral terhadap kelompok sosial. Hal itu diungkapkan oleh keempat informan berikut ini

"Selain sekolah dia juga ngaji gitu”. (If.2)

"Dia ngaji TPA, kayak paud lagi gitu... biasa aja sih kayak sekolah lagi... malah jadi 2 kali tapi dua duanya kayak paud gitu”. (If.3)

"TPA juga dia ngaji, setiap hari senin sampai jumat”. (If.4)

"Dia aktivitasnya paling sekolah dan ngaji aja”. (If.5)

Wafirah (2013) menyatakan bahwa pendidikan yang baik serta pengetahuan yang luas menjadi kunci keberhasilan dalam menjalankan peran sebagai anak. Orang tua juga memiliki kewajiban untuk meningkatkan pengetahuan dan pendidikan anak agar bisa mengembangkan kemampuan sesuai tahap perkembangan, mendapatkan informasi yang tepat, belajar menyelesaikan masalah serta bisa menunjukan penerimaan terhadap sakitnya. Hal tersebut diungkapkan oleh informan kedua berikut ini 
"Merawat diri sendiri dan hati juga itu yang utama, saya selalu bilang ke anak saya, sok berdoa sama Allah, walaupun lagi sakit seperti sekarang saya selalu bilang seperti itu, obat minum tapi yang dapat menyebuhkan kamu bukan obat ini, saya selalu memberikan pondasi seperti itu kepada anak... kamu solat minta sama yang diatas kalau kamu ingin sembuh (If.2)

"Jiwanya dikuatin, dia jadi kuat, anak aku harus sehat, aku mengajarkan bahwa dia gak sakit gitu... dede kamu gak usah takut, aku juga harus mengajarkan ke anak aku, ini mamah aja kuat, gak boleh lemah, gak boleh nangis, karena kalau misalkan dede gak kuat mau sama siapa lagi, jadi aku mah nerapin nya yah gitu”. (If.3)

Peneliti melihat bahwa selain pemahaman ARV terkait fungsi medis, memaknai ARV terkait fungsi spiritual juga memberikan harapan hidup yang positif sehingga meningkatkan kepatuhan pengobatan. Menurut Kyle dan Carman (2014) spiritualitas merupakan fokus penting ketika bekerja sama dengan anak-anak. Hasil penelitian Bert (2011) dalam Sujana, Fatimah \& Hidayati (2017) pada 110 ibu yang memiliki anak remaja menunjukan bahwa spiritualitas ibu merupakan prediktor kuat antara ibu dan anak. Anak yang mendapatkan pemahaman spiritual dapat menerima dengan ikhlas sakit yang dideritanya, mampu mengambil pelajaran serta memiliki harapan yang realistis terhadap kesembuhan.

Adhim (2010) mengatakan orang tua perlu mengingatkan dan menumbuhkan niat anak dalam belajar. Anak akan memiliki pertahanan diri yang didapatkan dari proses mengingat dan dipelajari sejak awal timbulnya masalah serta menyadari dampak dari masalah tersebut. Hal itu diungkapkan oleh kedua informan berikut.

"Dia tahu ada virus dalam tubuhnya, dia tahu kekebalan tubuhnya lemah, dia tahu harus patuh minum obat namanya ARV... dia tahu tertular dari ibunya, dan dia harus takut akan jangka panjang apabila tidak disiplin, dia harus menjaga kesehatan karena daya tahan tubuhnya lemah". (If.6)

"Saya menjelaskan ke anak kondisi kamu kan beda dengan yang lain, artinya daya tahan tubuh kamu lebih cepat menurun dibandingkan teteh kamu atau adik kamu yang lain" (If.2)

Orang tua bukan hanya mendorong anak untuk tetap pergi ke sekolah, tetapi juga aktif beraktivitas seperti olahraga yang sesuai dengan kemampuannya. Kegiatan olahraga yang disenangi seperti berenang atau bersepeda akan membantu anak untuk tetap mengikuti program tersebut. Hal itu diungkapkan oleh ketiga informan berikut ini.

"Waktu itu pernah sendirian naik sepeda ke kakeknya... futsal anak ini mah hobby". (If.1)

"Paling main bola disekolah... olahraga ke gasibu”. (If.5)

"Dia sibuk banget, senin sampai jumat sekolah, selasa sama jumat renang, senin dia less inggris, hari sabtu minggu dia futsal, dan dia bisa sehat dengan pantauan dokter, setelah olahraga kesehatan dia jadi lebih membaik, karena nafsu makan bertambah, tidur teratur, metabolisme 
jadi lebih baik, karena pembuangan zat-zat yang tidak perlu lebih baik". (If.6)

Menurut Nursalam (2009) olahraga yang dilakukan secara teratur menimbulkan adaptasi organ tubuh yang berefek menyehatkan dan menghasilkan perubahan pada jaringan, sel, serta protein pada sistem imun. Olahraga memang tidak dapat melawan penyakit HIV/AIDS, tetapi dapat membantu ODHA merasa lebih sehat dan mengurangi efek samping dari obat ARV yang dipakai.

\section{PENUTUP}

New insight dalam penelitian ini, yaitu orang tua yang merawat anak dengan HIV/AIDS merasa takut untuk mengungkapkan status HIV kepada anaknya karena orang tua merasa khawatir anak yang mengetahui status akan mengalami pemberontakan, kesedihan, atau mengalami masalah kesehatan mental sehingga orang tua lebih memilih berbohong kepada anak tentang statusnya. Kerahasiaan status yang dilakukan orang tua juga diakibatkan ketakutan pada stigma dan diskriminasi dari masyarakat awam yang tidak mengetahui cara penularan penyakit HIV/AIDS sehingga khawatir akan diperlakukan berbeda dibandingkan dengan orang yang menderita penyakit lain. Orang tua juga belum memberitahukan status HIV anak mereka kepada pihak sekolah karena merasa takut akan menimbulkan stigma dan diskriminasi dari guru dan temannya.
Peran orang tua sangat penting dalam memberikan dukungan dan perawatan kepada anaknya dengan selalu meningkatkan motivasi dan pengawasan agar anak tetap mematuhi pengobatan. Diharapkan, kedepannya, permasalahan yang berkaitan dengan ADHA dapat menjadi prioritas dan ditanggulangi secara maksimal.

\section{DAFTAR PUSTAKA}

Adhim, M. F. (2013). Didik mereka jadi pemberani. Majalah Suara Hidayatullah. Edisi Oktober 2012. Surabaya

Avert. (2011). Children, HIV and AIDS. http://www.avert.org/children.htm. diakses 25 Maret 2018

Ardana, E. (2014). Resiliensi Orang dengan HIV/AIDS (ODHA) (Doctoral dissertation unpublished, Universitas Islam Negeri Maulana Malik Ibrahim).

Burhan R.F., Listyawati E.F., \& Zuhroni. (2014). Gambaran kebermaknaan hidup orang dengan HIV/AIDS (ODHA) serta tinjauannya menurut islam. Vol. 2. Fakultas Psikologi Universitas YARSI. Jurnal Psikogenesis.

Badahdah AM, \& Pedersen DE. (2011). I want to stand on my own legs: A qualitative study of antiretroviral therapy adherence among HIV-positive women in Egypt. AIDS Care. Juni 2011. 23(6):700-4

Chambers, L. A., Rueda, S., Baker, D. N., Wilson, M. G., Deutsch, R., Raeifar, E., \& Rourke, S. B. (2015). Stigma, HIV and health: a qualitative synthesis. $B M C$ Public Health, 15(1), 848.

Cohen, M. S., Chen, Y. Q., McCauley, M., Gamble, T., Hosseinipour, M. C., Kumarasamy, N., ... \& Godbole, S. V. (2011). Prevention of HIV-1 infection with early antiretroviral therapy. New England journal of medicine, 365(6), 493-505. 
Ernawati. (2013). Sikap pengasuh anak balita yang terinfeksi HIV/AIDS Di Kabupaten Temanggung dan Kudus. Program Studi S 1 Keperawatan, Fakultas Ilmu Keperawatan dan Kesehatan, Universitas Muhammadiyah Semarang. Jurnal Keperawatan Komunitas. 1 (1): 62-73

Fathimah, F. (2013). Gambaran orang tua/pengaruh dalam memberikan makanan bergizi kepada anak terinfeksi human immunodeficiency virus di Yayasan Tegak Tegar Wiayah Jakarta Timur Tahun 2013.

Felix, G., \& Ceolim, M. F. (2012). The profile of women with HIV/AIDS and their adherence to the antiretroviral therapy. Revista da Escola de Enfermagem da USP, 46(4), 884-891.

Friedman, M. M., Bowden, V. R., \& Jones, E. G. (2010). Buku ajar keperawatan keluarga: Riset, Teori dan Praktek. Jakarta: EGC, 5-6.

Hockenberry, M. J. (2009). Wilson D. Wong's essentials of pediatric nursing, 8 .

Kyle, T \& Carman, S. 2014. Buku Ajar Keperawatan Pediatrik. Edisi 1. EGC. Jakarta

Kaay, FA. (2016). Stress ibu hamil usia remaja yang melakukan pemeriksaan HIV/AIDS dan dinyatakan positif HIV/AIDS di Puskesmas Kota Wamena (Studi Kasus Terhadap Pasien Voluntary Counseling Testing). Skripsi. Program Studi Fakultas Psikologi. Universitas Kristen Satya Wacana: Salatiga.

Legiati, Shaluhiyah \& Suryoputro. (2012). Perilaku ibu hamil untuk Tes HIV di Kelurahan Bandarharjo dan Tanjung Mas Kota Semarang. Politeknik Kesehatan Kemenkes Jurusan Kebidanan Bandung \& Magister Promosi Kesehatan Universitas Diponegoro Semarang. Jurnal Promosi Kesehatan Indonesia. 7 (2). titi.legiati@yahoo.com. diakses 10 Juni 2018.
Lubis, L., Sarumpaet, S. M., \& Ismayadi, I. (2016). Hubungan stigma, depresi dan kelelahan dengan kualitas hidup HIV/AIDS di Klinik Veteran Medan. Idea Nursing Journal, 7(1), 113.

Mahdavi, S., Malyuta, R., Semenenko, I., Pilipenko, T., \& Thorne, C. (2010). Treatment and disease progression in a birth cohort of vertically HIV-1 infected children in Ukraine. BMC pediatrics, 10(1), 85.

Marlinda, E. (2011). Pengalaman Ibu dalam Merawat Anak Berkebutuhan Khusus: Autisdi Banjar Baru Kalimantan Selatan (Doctoral dissertation, Tesis).

Mboi, N. (2011). Dampak Epidemi Ganda AIDS dan Narkoba pada Anak Indonesia. http://www.ifppd.org/detail/newsforum. php?id=11. diakses 25 Mei 2018

Muhaimin, T. (2010). Impact of HIV/AIDS in the family on children's quality of life. Medical Journal of Indonesia, 19(4), 280-6.

Nursalam \& Kurniawati, N.D. (2014). Asuhan Keperawatan pada Pasien Terinfeksi HIV/AIDS. Jakarta: Salemba Medika

Polit, D. F., \& Beck, C. T. (2010). Essentials of nursing research: Appraising evidence for nursing practice. Lippincott Williams \& Wilkins.

Shintawati I. (2014). Faktor Pendukung dan Penghambat Kepatuhan Penggunaan Obat: Studi Kualitatif Pada Pasien HIV/AIDS dengan Terapi Antiretroviral Lini Kedua di Provinsi D.I. Yogyakarta. Skripsi

Sujana ES, Fatimah \& Hidayati N.O. (2017). Kebutuhan Spiritual Keluarga Dengan Anak Penderita Penyakit Kronis. Departemen Keperawatan Jiwa Fakultas Keperawatan Universitas Padjadjaran. Jurnal Pendidikan Keperawatan Indonesia. 3 (1):47-56 
Tindyebwa, D., Kayita, J., Musoke, P., Eley, B., Nduati, R., \& Tumwesigye, N. (2011). Handbook on paediatric AIDS in Africa by the African Network for the care of children affected by HIV/AIDS (ANNECA). Kampala, Uganda: ANECCA Secretariat. Retrieved April, 11, 2015.

UNAIDS. (2010). UNAIDS report on the global AIDS epidemi'. Children, HIV and

AIDS. http://www.avert.org/children.htm. diakses 10 Juni 2018.

UNICEF. (2011). Caring for Children Affected by HIV and AIDS. http://www.unicefirc.org/publication/pdf/insight-hiveng.pdf. diakses 10 Juni 2018.

Wachdin, F. R., Murti, B., \& Demartoto, A. (2017). Phenomenology Study: Community Non Acceptance of Children with HIV/AIDS in Surakarta. Journal of Epidemiology and Public Health, 1(3), 148-153.

Wahyuni WB, Widjanarko \& Shaluhiyah Z. (2014). Partisipasi Orang Dengan HIV/AIDS (ODHA) Ibu Rumah Tangga pada Program Prevention Of Mother to Child Transmission (PMTCT) di Kota Semarang. Jurnal Promosi Kesehatan Indonesia. Volume 9 (2). Magister Promosi Kesehatan Universitas Diponegoro.

WHO. (2011). WHO Director-General calls for more synergies to achieve millennium development goal on mothers, children and hIV. http://www.who.int/hiv/mediacentre/mt ct/en/index.html. New York. tanggal 25 Mei 2018

Willyane \& Giselle. (2014). Experience of taking care of children exposed to HIV: a trajectory of expectations. Revista Latino-Americana de Enfermagem. www.eerp.usp.br/rlae
Yayasan Spiritia, (2014). Saya berhak tahu... dan saya berhak mengungkapkan. E-mail: info@spiritia.or.id. http://spiritia.or.id/. diakses 10 Juni 2018.

Yuniar, Y., Handayani, R. S., \& Aryastami, N. K. (2013). Faktor-faktor pendukung kepatuhan orang dengan HIV AIDS (ODHA) dalam minum obat antiretroviral di Kota Bandung dan Cimahi. Buletin Penelitian 